\title{
7. TESTING MODELS OF FISSION TRACK ANNEALING IN APATITE IN A SIMPLE THERMAL SETTING: SITE 800, LEG 129
}

\author{
Peter Vrolijk, ${ }^{2}$ Raymond A. Donelick, ${ }^{3}$ John Queng, ${ }^{2,4}$ and Mark Cloos ${ }^{3}$
}

\begin{abstract}
Four models of fission track annealing in apatite are compared with measured fission track lengths in samples from Site 800 in the East Mariana Basin, Ocean Drilling Program Leg 129, given an independently determined temperature history. The temperature history of Site 800 was calculated using a one-dimensional, compactive, conductive heat flow model assuming two end-member thermal cases: one for cooling of Jurassic ocean crust that has experienced no subsequent heating, and one for cooling of Cretaceous ocean crust. Because the samples analyzed were only shallowly buried and because the tectonic history of the area since sample deposition is simple, resolution of the temperature history is high. The maximum temperature experienced by the sampled bed is between $16^{\circ}-21^{\circ} \mathrm{C}$ and occurs at $96 \mathrm{Ma}$; temperatures since the Cretaceous have dropped in spite of continued pelagic sediment deposition because heat flow has continued to decay exponentially and bottom-water temperatures have dropped. Fission tracks observed within apatite grains from the sampled bed are $14.6 \pm 0.1 \mu \mathrm{m}(1 \sigma)$ long. Given the proposed temperature history of the samples, one unpublished and three published models of fission track annealing predict mean track lengths from 14.8 to $15.9 \mu \mathrm{m}$. These models require temperatures as much as $40^{\circ} \mathrm{C}$ higher than the calculated paleotemperature maximum of the sampled bed to produce the same degree of track annealing. Measured and predicted values are different because annealing models are based on extrapolation of high temperature laboratory data to geologic times. The model that makes the closest prediction is based on the greatest number of experiments performed at low temperature and on an apatite having composition closest to that of the core samples.
\end{abstract}

\section{INTRODUCTION}

Charged-particle tracks in dielectric solids are zones of intense crystallographic damage that form by the passage of highly charged ions through crystal lattices (e.g., Silk and Barnes, 1959; Price and Walker, 1962). Fission tracks in apatite are charged-particle tracks that form following the fission decay of their parent isotope (typically ${ }^{238} \mathrm{U}$ in nature and ${ }^{235} \mathrm{U}$ in a nuclear reactor). Fission tracks in all U-bearing solids, including apatite, accumulate over long periods of time but are partially annealed (repaired) with heating over geologic times relative to their experimentally produced counterparts (e.g., Price et al., 1973; Green, 1980; Donelick et al., 1990, and references therein). This is to be expected because charged-particle tracks are metastable zones of crystallographic damage that exhibit a natural tendency to anneal at ambient temperatures. Of particular interest to geologists are apatite fission tracks because their etchable length distributions, in combination with conventional fission track age determinations, are routinely used to study thermal histories of rocks below $\sim 130^{\circ} \mathrm{C}$ (e.g., Gleadow et al., 1986). Fission tracks in apatite are unique among thermochronometric methods because (1) new fission track populations form continuously through time by the spontaneous fission of ${ }^{238} \mathrm{U}$ and (2) individual track populations are distinguishable from one another based upon their mean confined etchable lengths (e.g., Green et al., 1986; Donelick, 1991; Crowley et al., 1991). As a consequence of these characteristics, naturally occurring fission tracks in apatite record detailed time-temperature path information experienced by their host rock (Green et al., 1989; Donelick and Willett, 1989; Corrigan, 1991).

\footnotetext{
'Larson, R. L., Lancelot, Y., et al., 1992. Proc. ODP, Sci. Results, 129; College Station, TX (Ocean Drilling Program). U.S.A.

EXXON Production Research Company, P.O. Box 2189, Houston, TX 77252-2189.

${ }^{3}$ Department of Geological Sciences, University of Texas at Austin, P.O. Box 7909, Austin, TX 78713-7909, U.S.A.

${ }^{4}$ Current address: 5742 Reamer, Houston, TX 77096, U.S.A.
}

Temperature history has the greatest influence on charged-particle track stability (e.g., Fleischer et al., 1965). In apatite, however, track orientation (e.g., Green and Durrani, 1977; Donelick, 1991) and apatite chemistry (e.g., Green et al., 1986) are important secondary effects. The purpose of this paper is to present new constraints on the distribution of confined etchable track lengths in apatite at relatively low temperatures $\left(<30^{\circ} \mathrm{C}\right)$ over geological time. These results are compared to the geological predictions of four laboratorybased calibrations of fission track annealing (three published, one unpublished). The discussion below begins by introducing these laboratory calibrations.

\section{MODELS OF FISSION TRACK ANNEALING IN APATITE}

In their quantitative analysis of the Durango apatite annealing data of Green et al. (1986), Laslett et al. (1987) found that the fanning-linear Arrhenius model provides the best empirical description of mean etchable fission track length vs. time and temperature of isothermal annealing. Crowley et al. (1991), in a similar quantitative analysis of their own annealing data for a near-end-member fluorapatite, arrived at the same conclusion. Consequently, R. Donelick and S. Willett (unpubl. data, 1989) applied the Crowley et al. (1991) model to the Tioga apatite annealing data of Donelick et al. (1990), Donelick (1991), and R. Donelick (unpubl. data, 1989). Geometrically, the fanning-linear Arrhenius model describes a surface characterized by $x$-values equal to $1 / T(T=$ isothermal annealing temperature in $\mathrm{K})$, $y$-values equal to $\ln (t)(t=$ annealing time in seconds [s]), and $z$-values equal to reduced mean confined fission track length $l / l_{o}\left(l_{o}=\right.$ "initial" mean track length; $l=$ mean track length for the experiment). Contours of the surface projected onto the $1 / T-\ln (t)$ plane (i.e., Arrhenius space) are linear and fan out from a point, thus the namesake of the model. Moreover, this model reflects a progressive increase in the activation energy necessary to accomplish each increment of annealing; tracks become harder to anneal as they shorten.

Carlson (1990) presented a model of etchable fission track length in apatite that assumes a track geometry and empirical expressions 
for the axial and radial defect density distributions of the unetched fission tracks. The model further holds that etching proceeds rapidly along the damage zone of the track until relatively undisturbed, more slowly etched bulk crystal is encountered. The process of track annealing is described as a process of defect elimination characterized by a single activation energy, a model producing results similar to the parallel-linear models of Laslett et al. (1987) and Crowley et al. (1991). Geometrically, the parallel-linear Arrhenius model differs from the fanning-linear Arrhenius model by having parallel contours of mean track length in the $1 / T-\ln (t)$ projection.

The critical question governing the usefulness to the geologist of all of these models is: Do the kinetic models above accurately describe fission track annealing over geological time, and therefore lead to accurate predictions of geological thermal histories? The only way to answer this question is to identify a geological setting for which the thermal history is accurately known and determine what effect that thermal history has had on fission tracks in apatite. Samples that have remained near Earth's surface throughout their history have two advantages for studying natural annealing processes: their temperature histories are usually uncomplicated by basin-forming or other thermal events, and their results represent an extreme case of annealing. Because ocean water temperatures in deep water settings can vary by only a few degrees through geologic time and the surface temperature of continents may vary by tens of degrees Celsius depending on climatic conditions, the temperature history of sediments in deep ocean basins is best known.

\section{GEOLOGICAL SETTING}

In choosing a setting to define the degree of fission-track shortening in apatite for a low-temperature history, two criteria were imposed: the grains must only have been heated slightly for long $(>10$ m.y.) periods, and the tectonic and thermal histories of the samples must be simple and accurate. We looked to the oceans for such samples because the ocean water column offers a much better thermal buffer than the atmosphere, heat flow in oceanic crust is better understood than that in continental crust, and transient thermal effects due to groundwater flow and erosion may be more easily eliminated from consideration. The samples collected on Ocean Drilling Program (ODP) Leg 129 best fit these criteria following examination of all occurrences of Miocene and older volcanic ash in the Deep Sea Drilling Program (DSDP)/ODP database.

Leg 129 (Fig. 1) was undertaken to sample Mesozoic pelagic deposits and Jurassic ocean crust in the western Pacific. Three sites $(800,801$, and 802$)$ were drilled in the Pigafetta and East Mariana Basin in the vicinity of magnetic lineations interpreted to be Jurassic in age (Lancelot, Larson, et al., 1990). The sediments recovered on this cruise include thin Tertiary pelagic brown clays with minor chert, porcelanite and radiolarite, Upper Cretaceous porcelanite, chalk, and limestone, Lower Cretaceous volcaniclastic turbidite beds, and Upper Jurassic to Lower Cretaceous radiolarite and claystone. The Mesozoic volcaniclastic deposits range in age from Aptian at Site 800 to Albian-Cenomanian (Site 801) to Santonian-Turonian (Site 802).

Only Site 801 reached Jurassic ocean crust. Site 800 ended in dolerite sills that have been intruded into Berriasian claystones and cherts. The dolerites are $126 \pm 1 \mathrm{Ma}$, based on ${ }^{40} \mathrm{Ar} /{ }^{39} \mathrm{Ar}$ laser-fusion ages of three mineral components in two samples (Pringle and Castillo, this volume). At Site 802, Albian claystones and tuffs are underlain by olivine-bearing pillow basalts.

\section{Volcaniclastic Beds: Source of Apatite}

The volcaniclastic sediments at Sites 800 and 801 were sampled throughout their entire extent (Table 1). At Site 800, the entire sequence (Unit IV of Lancelot, Larson, et al., 1990; includes Cores 129-800A-26R to $-50 \mathrm{R}, 228.6-449.6 \mathrm{mbsf}$ ) has been divided into three subunits (Lan-

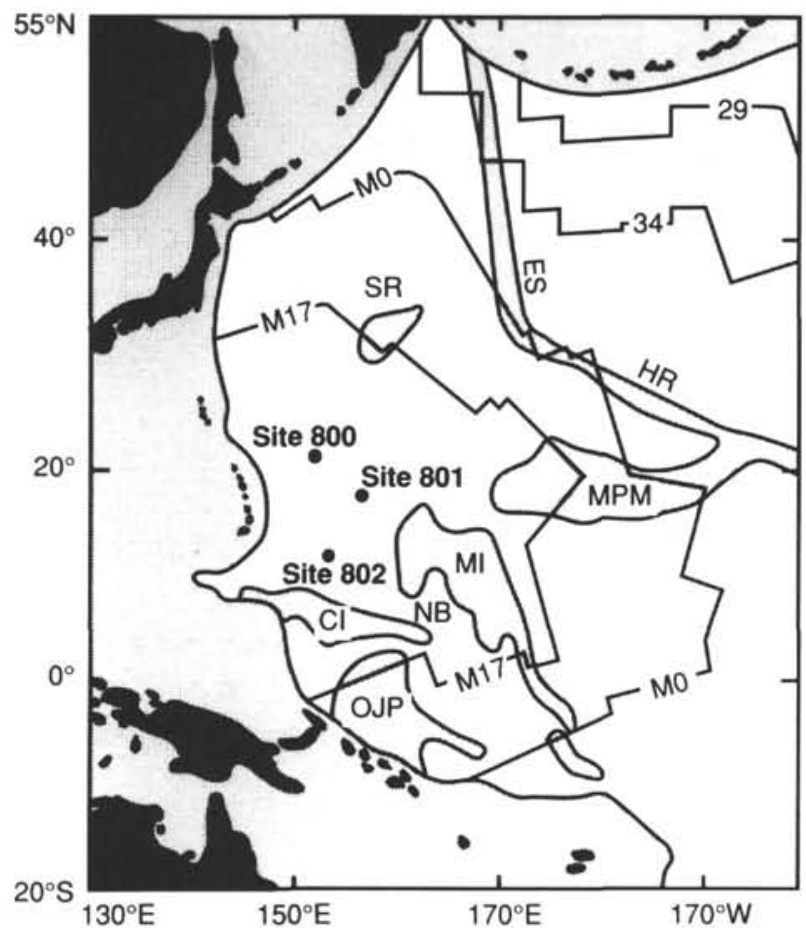

Figure 1. Location map of Leg 129, Sites 800,801, and 802. (Map from Lancelot, Larson, et al., 1990). SR = Shatsky Rise, ES = Emperor Seamounts, HR = Hawaiian Ridge, MPM = Mid-Pacific Mountains, $\mathrm{MI}=$ Marshall Islands, $\mathrm{CI}=$ Caroline Islands, $\mathrm{NB}=\mathrm{Nauru}$ Basin, $\mathrm{OJP}=$ Ontong Java Plateau. Jagged contours represent magnetic lineations and unshaded areas represent normal Pacific oceanic crust. Shaded areas represent volcanic edifices with thickened crustal sections, as well as the younger areas beyond the Pacific subduction zones.

celot, Larson, et al., 1990). First, a lower unit (343.8-449.6 mbsf) consists of coarse-grained, massive beds with no calcareous biogenic constituents. The extent of alteration of these deposits led the shipboard scientists to conclude that these deposits accumulated near an active volcanic source. These sediments are undated, but they overlie Hauterivian-Barremian(?) radiolarites. Second, the middle unit (278.1-343.8 mbsf) contains similar volcaniclastic detritus but significant shallowwater calcareous detritus, indicating near sea-level erosion of an active volcanic seamount. The lower part of this subunit is undated, but the upper part contains early Aptian nannofossils. Third, beds in the upper unit (228.6-278.1 mbsf) become thinner, finer-grained, and more finely laminated, and grade upward into more siliceous deposits. Most of the subunit contains early Aptian nannofossils, but the uppermost two cores contain late Aptian nannofossils.

The volcaniclastic deposits are roughly coeval with the intruded $126 \mathrm{Ma}$ dolerites below. The base of the unit may be Hauterivian-Barremian in age (119-131 Ma on the Decade of North American Geology [DNAG] time scale), whereas the top of the unit may be as young as $113 \mathrm{Ma}$ (again based on the DNAG time scale). However, there are significant differences in published time scales. Using the time scale of Harland et al. (1989), the base of the unit may be as old as $124.5-131.8 \mathrm{Ma}$, and the top as young as $112 \mathrm{Ma}$. According to $\mathrm{Haq}$ and van Eysinga (1987), the older ages range from 115 to 130 $\mathrm{Ma}$ and the young age is $108 \mathrm{Ma}$. Geological evidence suggests that the Berriasian-Barremian claystone and radiolarite were diagenetically altered by intrusion of the dikes. However, none of the contact metamorphic or diagenetic features identified in these beds has been described in the volcaniclastic units (Lancelot, Larson, et al., 1990), with the exception of calcite-, zeolite-, and clay-filled fractures. Samples dredged from nearby Himu Seamount, located $60 \mathrm{~km}$ to the 
Table 1. Description of composite sample.

\begin{tabular}{|c|c|c|c|c|c|}
\hline $\begin{array}{l}\text { Sample } \\
\text { name }\end{array}$ & Core interval & $\begin{array}{l}\text { Depth interval } \\
\text { (mbsf) }\end{array}$ & $\begin{array}{l}\text { Processing } \\
\text { completed }\end{array}$ & $\begin{array}{c}\text { Apatite } \\
\text { yield }\end{array}$ & $\begin{array}{r}\text { Analysis } \\
\text { completed }\end{array}$ \\
\hline MB-1 & $129-801 \mathrm{~A}-16 \mathrm{R}-1$ to $18 \mathrm{R}-1$ & $146.02-166.44$ & No & & \\
\hline MB-2 & $129-801 \mathrm{~B}-1 \mathrm{R}-1$ to $4 \mathrm{R}-1$ & $194.73-222.56$ & Yes & Poor & No \\
\hline MB-3 & $129-801 \mathrm{~B}-5 \mathrm{R}-1$ to $8 \mathrm{R}-5$ & $231.96-267.72$ & Yes & Poor & No \\
\hline MB-4 & $129-801 \mathrm{~B}-12 \mathrm{R}-1$ to $13 \mathrm{R}-\mathrm{CC}$ & $299.57-310.08$ & No & & \\
\hline MB-5 & $129-800 \mathrm{~A}-26 \mathrm{R}-1$ to $27 \mathrm{R}-\mathrm{CC}$ & $229.19-240.14$ & No & & \\
\hline MB-6 & $129-800 \mathrm{~A}-28 \mathrm{R}-1$ to $29 \mathrm{R}-\mathrm{CC}$ & $247.94-260.64$ & Yes & Poor & No \\
\hline MB-7 & $129-800 \mathrm{~A}-30 \mathrm{R}-1$ to $32 \mathrm{R}-2$ & $266.04-280.42$ & Yes & Good & Yes \\
\hline MB-8 & $129-800 \mathrm{~A}-33 \mathrm{R}-1$ to $35 \mathrm{R}-3$ & $288.94-310.05$ & Yes & Fair & Yes \\
\hline MB-9 & $129-800 \mathrm{~A}-36 \mathrm{R}-1$ to $37 \mathrm{R}-\mathrm{CC}$ & $316.33-328.14$ & Yes & Fair & No \\
\hline MB-10 & $129-800 \mathrm{~A}-39 \mathrm{R}-1$ to $43 \mathrm{R}-1$ & $344.25-375.73$ & Yes & Fair & Yes \\
\hline MB-11 & $129-800 \mathrm{~A}-44 \mathrm{R}-1$ to $46 \mathrm{R}-\mathrm{CC}$ & $384.21-407.73$ & Yes & Poor & No \\
\hline MB-12 & $129-800 \mathrm{~A}-47 \mathrm{R}-1$ to $48 \mathrm{R}-5$ & $412.65-428.42$ & Yes & Poor & No \\
\hline MB-13 & $129-800 \mathrm{~A}-49 \mathrm{R}-1$ to $50 \mathrm{R}-\mathrm{CC}$ & $431.97-443.57$ & Yes & Poor & No \\
\hline
\end{tabular}

southwest of Site 800 , yield ${ }^{40} \mathrm{Ar} /{ }^{39} \mathrm{Ar}$ ages of $120-121 \mathrm{Ma}$ (Smith et al., 1989). This suggests that eruption of the volcaniclastic deposits postdated the dolerite sills at Site 800 by a short time interval, but the time resolution is too poor to confirm this.

\section{SAMPLE DETAILS AND EXPERIMENTAL PROCEDURES}

The composite samples of all volcaniclastic core samples collected from Sites 800 and 801 for fission track analysis are listed in Table 1 . Thirteen composite samples were formed by grouping individual core samples from depth intervals ranging from 11 to $36 \mathrm{~m}$. Also included in Table 1 are the processing status, apatite yield, and analysis status for each composite sample.

Each processed composite sample was subjected to standard heavy liquid and magnetic-mineral separation techniques aimed at isolating any apatite present. Four composite samples yielded visible apatite (MB-7, -8, -9, and -10; Table 1); of these only MB-9 was not processed further because of the small amount of apatite recovered. The apatite from the remaining three samples was slightly magnetic and required hand-picking to obtain sufficiently pure separates for analysis. Most of the recovered apatite grains are euhedral but some are very well rounded, suggesting significant abrasion during sediment transport (Fig. 2). Two groups of epoxy mounts were made and polished: Group A consists of one mount for each composite sample containing the hand-picked apatite grains; Group B consists of one mount for each composite sample containing a large number of the grains left behind after hand-picking. Group B grain mounts were etched in $5.5 \mathrm{M} \mathrm{HNO}_{3}$ for $25 \mathrm{~s}$ at $21^{\circ} \mathrm{C}$, and several apatite grains, missed during the picking process, were identified on each. It was observed that the spontaneous fission track densities were on the order of $10^{6}$ tracks $/ \mathrm{cm}^{2}$, indicating that there would be few confined fission tracks available for measurement in the few grains available in the Group A grain mounts. In light of this observation, fission fragment tracks from a planar ${ }^{252} \mathrm{Cf}$ source, in the amount of approximately $3 \times 10^{6}$ tracks $/ \mathrm{cm}^{2}$, were added to each of the Group A mounts prior to chemical etching as above in order to increase the number of fission tracks for which length measurements could be obtained (Donelick and Miller, 1991). This procedure produced an estimated three-fold increase in the number of confined fission tracks available for measurement (Fig. 3).

Only horizontal, confined fission tracks lying in crystallographic planes parallel to the $c$-axis were measured in this study. Tracks were viewed in unpolarized transmitted light at $1600 \times(10 \times$ ocular, $1.6 \times$ microscope tube, $100 \times$ dry objective). Individual track lengths and angles to the $c$-axis were measured using a digitizing tablet interfaced with a personal computer. The cursor was positioned on the digitizing tablet with the aid of a projection tube attached to the microscope and a light-emitting diode attached to the cursor. The digitizing surface was calibrated using a 100 -lines $/ \mathrm{mm}$ micrometer. The measurement precision $(1 \sigma)$ of individual track lengths and angles to the $c$-axis were determined to be $\sim 0.2 \mu \mathrm{m}$ and $\sim 2^{\circ}$, respectively.

\section{ANALYTICAL RESULTS}

The fission-track lengths for samples MB-7 and MB-8 were subjected to both the conventional statistical analysis (distributed about their arithmetic mean length) and the elliptical statistical analysis (distributed about their best fit ellipse in polar coordinates), as described by Donelick (1991). These results, and the results of several standardization measurements performed on fission tracks in Durango apatite, are reported in Table 2. Fission track ages (pooled ages) for MB-7 and MB-8 are $112 \pm 7$ and $115 \pm 8$, respectively (Table 3 ). These ages are indistinguishable from the stratigraphic age of the sediment.

The chemical compositions of nine apatite grains from composite sample MB-10 were determined using a Cameca MBX electron microprobe with a beam current of $10 \mathrm{nA}$, operating voltage of $15 \mathrm{kV}$, a beam width of $10 \mu \mathrm{m}$, and 10 -s counting time (Table 4). The fluorine standard used was the Wilberforce apatite and data obtained for it and Durango apatite (same crystal as used by Donelick et al., 1990, and Donelick, 1991) during the same microprobe session are also reported.

\section{DISCUSSION}

\section{Temperature History of Volcaniclastic Beds}

The temperature history of sampled volcaniclastic beds was determined by using a one-dimensional, compactive, conductive heat flow model based on stretching and exponential cooling of the lithosphere as described by McKenzie (1978), McKenzie (1981), Parsons and Sclater (1977), and Royden et al. (1980). The temperature at the sediment-water interface $(5700 \mathrm{~m})$ at Site 800 is $0.4^{\circ} \mathrm{C}$ today (A. Fisher, pers. comm., 1991). For the model calculation, the sediment-water surface temperature rises to $5^{\circ} \mathrm{C}$ in the Pliocene, to $8^{\circ} \mathrm{C}$ in the Eocene, remains nearly constant through the Paleocene, then rises again to $10^{\circ} \mathrm{C}$ from the middle of the Cretaceous back through the Jurassic. Compaction of sediments is modeled using compaction curves for various lithologies that are averaged from curves obtained in sedimentary basins worldwide. Average values of thermal conductivity were assigned to each lithology, based on present-day, discrete measurements, and conductivity changes were modeled as a function of changing porosity during burial. The temperature history of a bed presently at $270 \mathrm{mbsf}$ corresponds to the approximate middle of the interval from which sample MB-7 was derived and was modeled given two end-member sets of boundary conditions. 


\section{A}

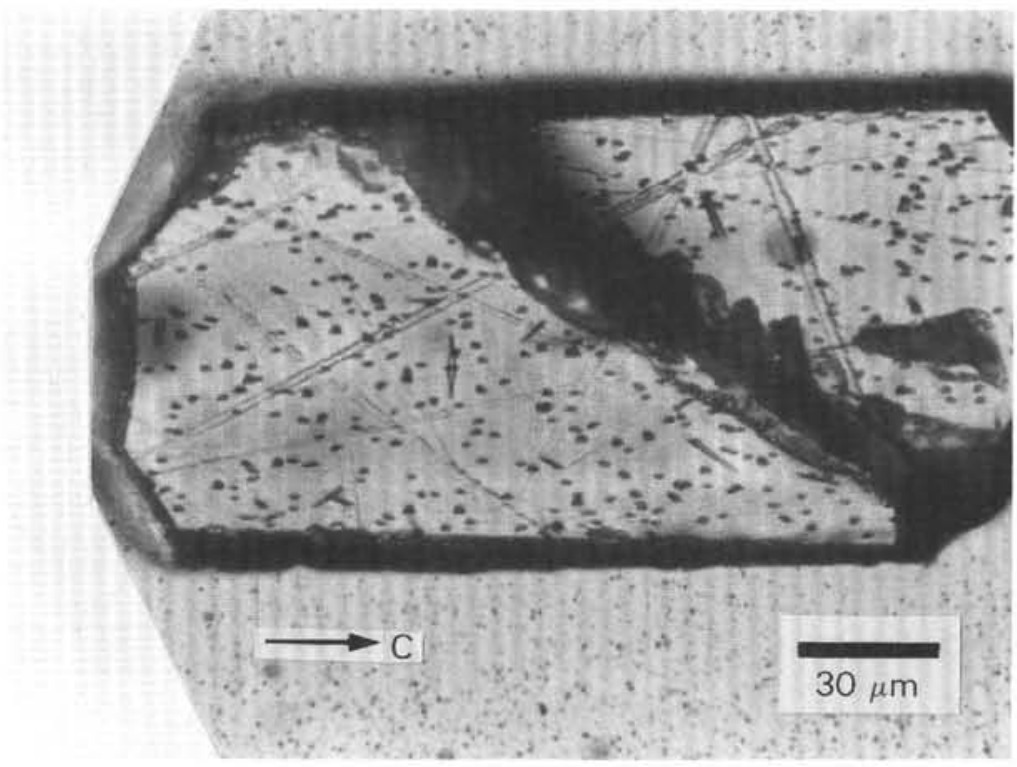

B

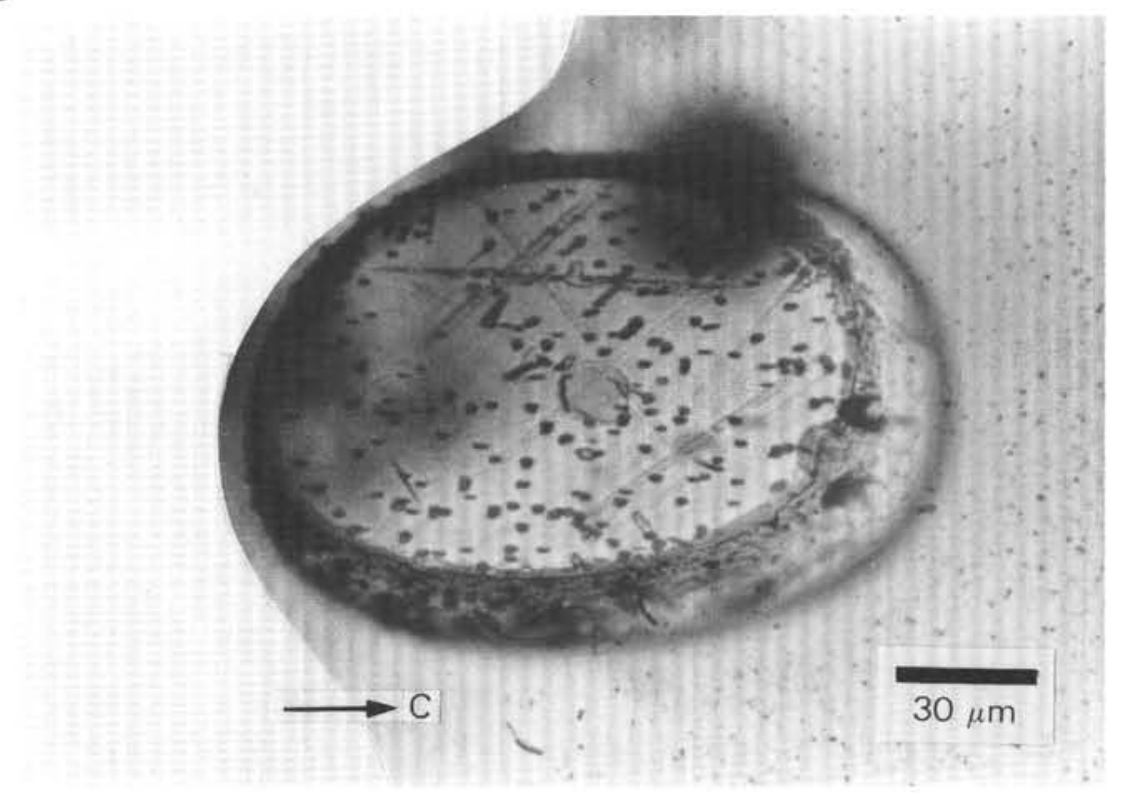

Figure 2. Photomicrographs of apatite grains from sample MB-7. A. Euhedral grain. B. Well-rounded grain. Crystallographic $c$-axis and length scale are indicated.

The ocean crust at Site 800 is favored to be Jurassic in age, based on interpretation of the seafloor magnetic lineations (Lancelot, Larson, et al., 1990). One thermal model was constructed presuming cooling of Jurassic (M33) ocean crust. Although the age of M33 is poorly known, a value of 163 Ma was used for the calculations; error in estimating its age as great as $æ 15 \mathrm{Ma}$ will have negligible effect on the temperature of beds deposited 50 m.y. later. In this model, the Cretaceous sills were assumed to have little thermal effect and were ignored. This assumption is rationalized by the thin interpreted thickness of the sills ( $45 \mathrm{~m}$ as inferred from seismic reflection profiles; Lancelot, Larson, et al., 1990) and the thin sediment cover above the sills ( $500 \mathrm{~m}$ today). The resulting temperature history of the sampled bed is presented in Figure 4.

An alternative interpretation is that the age of the ocean crust at Site 800 is $126 \mathrm{Ma}$, the age of the dolerite sampled at the base of the hole. A variation on this interpretation is that the crust is Jurassic, but the thickness of sills is so great that the emplacement of sills had the same thermal consequences as rifting. In these cases the sampled beds were deposited only 13 m.y. after rifting. However, because of the thin sediment cover at this site, the predicted maximum temperature experienced by the sampled bed is only $4.3^{\circ} \mathrm{C}$ higher than for the previous calculation (Fig. 4). 
A

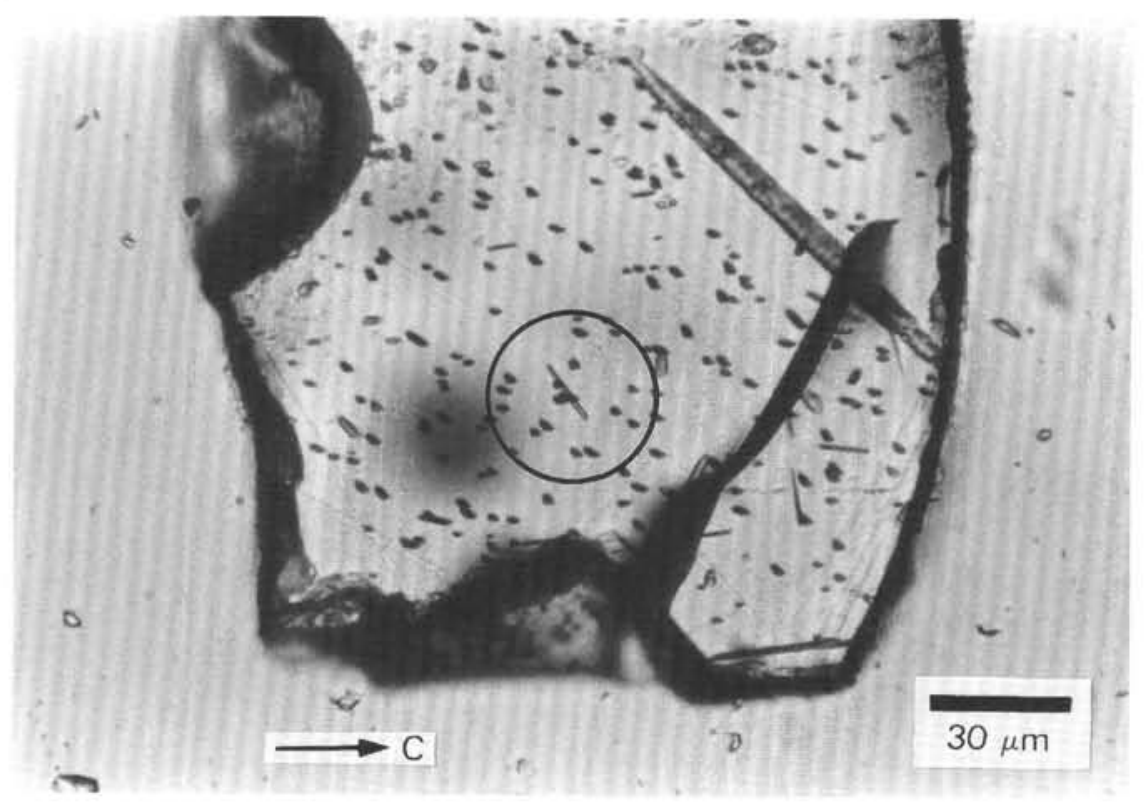

B

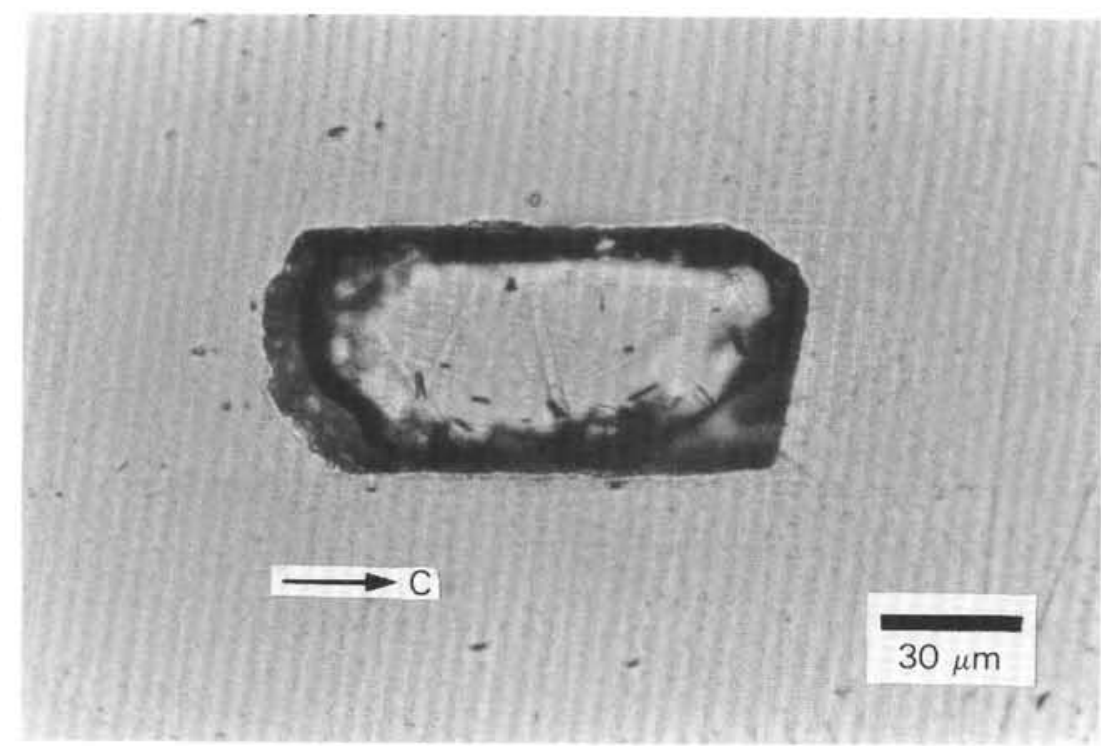

Figure 3. Photomicrographs of apatite grains from sample MB-7. A. Grain from mount Group A with numerous ${ }^{252} \mathrm{Cf}$ tracks and a confined fission track (indicated by circle) that appears to have been etched via $\mathrm{a}^{252} \mathrm{Cf}$ track. B. Grain from mount Group B with no ${ }^{252} \mathrm{Cf}$ fission tracks. Crystallographic $c$-axis and length scale are indicated.

\section{Additional Factors Affecting Temperature}

Hydrothermal circulation could alter the temperature history of the bed, which is calculated assuming one-dimensional heat conduction. However, assuming that the age of the detrital apatite grains is comparable to the age of the sediment (taken to be $113 \mathrm{Ma}$ ) and that hydrothermal activity occurred in the Cretaceous after rifting, hy- drothermal circulation would have to persist for more than $10 \%$ of the life of the grain (i.e., $>11 \mathrm{Ma}$ ) to produce a measurable affect on the distribution of fission track lengths. Later hydrothermal circulation is unlikely without more recent additional input of heat, which would be evident from bathymetry (i.e., a bathymetric swell).

Mineralized veins and faults in volcaniclastic sandstones at Site 800 suggest there may have once been hydrothermal circula- 
Table 2. Summary of measured track length data.

\begin{tabular}{lrrrrrrrrr}
\hline Sample & $N$ & $l_{m}$ & $\sigma_{l m}$ & $\sigma_{m}$ & $l_{c}$ & $\sigma_{l c}$ & $l_{a}$ & $\sigma_{l a}$ & $\sigma_{c}$ \\
\hline MB-7 & 166 & 14.6 & 0.1 & 1.0 & 15.4 & 0.2 & 14.1 & 0.1 & 0.9 \\
MB-8 & 35 & 14.3 & 0.2 & 1.0 & 15.0 & 0.3 & 14.0 & 0.2 & 1.0 \\
MB-10 & 2 & 13.4 & 0.2 & 1.2 & n.a. & n.a. & n.a. & n.a. & n.a. \\
anurango & 150 & 14.4 & 0.1 & 0.8 & 16.8 & 0.2 & 14.0 & 0.1 & 0.8 \\
b Durango & 150 & 16.2 & 0.1 & 0.8 & 16.8 & 0.2 & 15.9 & 0.1 & 0.8 \\
\hline
\end{tabular}

Note: $N=$ number of tracks; $l_{m}=$ arithmetic mean of track length; $\sigma_{l m}=$ standard error of $l_{m}: \sigma_{m}=$ standard deviation about $l_{m} ; l_{c}=$ mean track length parallel to $c$-axis; $\sigma_{l c}=$ standard error of $l_{i} ; l_{0}=$ mean track length parallel to $a$-axis; $\sigma_{l a}=$ standard error of $l_{\mathrm{a}}$; $\sigma_{e}=$ standard deviation about best-fit ellipse (after Donelick, 1991). n.a. =not analyzed. ac Contains natural fission tracks for use as a calibration standard (sample DR013 of Donelick and Miller, 1991).

${ }^{\mathrm{b}}$ Contains induced fission tracks for use as a calibration standard.

tion. Calcite veins contain aqueous fluid inclusions with only a single, liquid phase, indicating the calcite precipitated at temperatures $<50^{\circ} \mathrm{C}$. Approximately $15 \%$ of the inclusions have stretched or leaked, as evidenced by variable liquid/vapor ratios. However, there is no evidence to indicate when these inclusions were heated or deformed or what the magnitude of the inclusion deformation event was. The small proportion of deformed inclusions suggests that the deformation event was minor and could have even occurred some time after recovery of the core. Oxygen isotope analyses of calcite veins (Table 5) range from $27.2 \%$ to $30.5 \%$, and using the $\delta^{18} \mathrm{O}$ value of interstitial water today $(-2 \%$; C. France-Lanord, pers. comm., 1991) leads to estimates of the temperature of vein precipitation from $9^{\circ}$ to $23^{\circ} \mathrm{C}$, within the range of modeled temperatures and their uncertainties.

The temperature at the sediment-water interface will have a direct influence on the temperature of the sampled bed. There are two components that control bottom-water temperature: temperature of surface waters (with some knowledge of water depth), and movement of cold bottom waters. Temperatures at the sea-air interface can be estimated from paleoclimate models (e.g., Frakes, 1979) and plate reconstructions that limit paleolatitude (e.g., Engebretson et al., 1985). Generation of cold bottom-water currents at the poles depend further upon paleoclimate models (Frakes, 1979). Considering the uncertainties that compound from each of these estimates, the maximum uncertainty of the temperature at the sediment-water interface and hence of the modeled bed is estimated to be $\pm 5^{\circ} \mathrm{C}$ through time.

\section{Independent Estimates of Paleotemperature}

The continued presence of opal-CT at $267 \mathrm{mbsf}$ (Behl, this volume), within the depth interval of MB-7, suggests that temperatures were $<60^{\circ} \mathrm{C}$. X-ray diffraction (XRD) analyses of the light mineral fraction of MB-7, MB-8, and MB-10, obtained by bromoform separation (see above), yielded clinoptilolite as the only zeolite mineral present, in agreement with shipboard analyses (Lancelot, Larson, et al., 1990). Unfortunately the presence of clinoptilolite offers a poor limit on the maximum temperature the sample experienced.
Although temperature logs were included in the logging suite, there was insufficient time between drilling and logging to allow the temperature of the borehole to approach thermal equilibrium (A. Fisher, pers. comm., 1991). There is no way to decipher the present temperature state of the well at a high enough level of precision to distinguish the $0.9^{\circ} \mathrm{C}$ difference in present-day temperature at 270 mbsf predicted by Jurassic and Cretaceous rifting models (Fig. 4).

\section{Measured Data vs. Model Predictions}

Figure 5 illustrates the ability of each of the various apatite fission track annealing models to predict the mean track length measured for sample MB-7. It is assumed that the temperature history given in Figure $3 \mathrm{~B}$ for rifting at $126 \mathrm{Ma}$ is correct for this sample. If the temperature history for rifting at $163 \mathrm{Ma}$ is used, the modeled mean track lengths increase by less than $0.1 \mu \mathrm{m}$ for each model calculation. The Carlson (1990) model of the data of Green et al. (1986) does not predict the fission track annealing observed in sample MB-7 and is not considered further. Interestingly, the departure of the other three models from the measured mean track length for sample MB-7 correlates with chemical composition of the apatites used in the various experiments. In terms of weight percentage of $\mathrm{Cl}$ content, the apatites are arranged as follows: B-5 (Crowley et al., 1991) < Durango (Laslett et al., 1987) < Tioga (R. Donelick and S. Willett, unpubl. data, 1989). The B-5 apatite is closest in composition to the apatite from sample MB-7 (assuming it is the same composition as that from sample MB-10 based on similar size, habit, and etching features: Table 4) and the Crowley et al. (1991) model best predicts the measured track length data. However, the effect of the restricted range of chemical composition variation over which these models apply is insufficient to fully account for the inability of the Laslett et al. (1987) and R. Donelick and S. Willett (unpubl. data, 1989) models to accurately predict the track annealing exhibited by sample MB-7 (R. Donelick, unpubl. data, 1989).

The Laslett et al. (1987) model is most commonly used to interpret fission track length data from the geological environment. Assuming that the temperature history of sample MB-7 may be approximated by an episode of linear heating from 113 to $96 \mathrm{Ma}$ (initial temperature $10^{\circ} \mathrm{C}$ ) followed by an episode of linear cooling from 96 Ma to present day (final temperature $11^{\circ} \mathrm{C}$ ), we determine that a peak temperature of $59^{\circ} \mathrm{C}$ at 96 $\mathrm{Ma}$ is required by the Laslett et al. (1987) calibration to best fit the measured data. If a constant temperature history is assumed, this model requires a temperature of $34^{\circ} \mathrm{C}$ for the full 113 Maburial history of sample MB-7. Neither of these predictions is consistent with our calculated temperature histories for this sample. Peak temperatures as high as $59^{\circ} \mathrm{C}$ would be reflected in a broader track length distribution and more extensive transformation of opal-CT to quartz. To produce persistent temperatures of $34^{\circ} \mathrm{C}$, ocean bottom-water temperatures would have been at least $20^{\circ} \mathrm{C}$ warmer since the Cretaceous, or the conductive heat flux must have been much higher throughout this time, which is unlikely considering the bathymetry of the plate and the lack of a swell. Although the temperature history calculations are non-unique and contain some uncertainty $\left( \pm 5^{\circ} \mathrm{C}\right)$, it is impossible to construct a temperature history that

Table 3. Summary of measured fission track age data.

\begin{tabular}{cccccccccccc}
\hline Sample & $\rho_{\mathrm{s}}$ & $N_{\mathrm{s}}$ & $\rho_{\mathrm{i}}$ & $N_{\mathrm{i}}$ & $\rho_{\mathrm{d}}$ & $N_{\mathrm{d}}$ & $\begin{array}{c}\text { No. of } \\
\text { grains }\end{array}$ & $\chi^{2}$ & $\mathrm{Q}$ & $\begin{array}{c}\text { Pooled age } \\
(\mathrm{Ma})\end{array}$ & $\begin{array}{c}\text { Mean age } \\
(\mathrm{Ma})\end{array}$ \\
\hline MB-7 & 4.12 & 698 & 7.36 & 1246 & 33.96 & 4280 & 45 & 26.4 & 0.98 & $112 \pm 7$ & $125 \pm 8$ \\
MB-8 & 2.61 & 479 & 4.56 & 8373 & 4.174 & 2803 & 44 & 1.9 & 0.14 & $115 \pm 8$ & $142 \pm 17$ \\
\hline
\end{tabular}

Note: weighted mean $\zeta$-factor $=118.9 \pm 3.6 ; \rho=$ density of tracks $\left(\times 10^{5}\right)$ in tracks $/ \mathrm{cm}^{2} ; N=$ number of tracks measured; $\mathrm{s}$ $=$ spontaneous, $\mathrm{i}=$ induced, and $\mathrm{d}=$ in glass dosimeter; $\chi^{2}=$ result of statistical test; $Q=$ probability that $\chi^{2}$ value is greater than reported for a single population of grain ages (for values of $Q>0.05$, pooled age is more accurate); pooled age $=$ fission track age based on sum total of spontaneous and induced tracks for all grains; mean age $=$ arithmetic mean of individual grain fission track ages. 
Table 4. Summary of microprobe data.

\begin{tabular}{lcrr}
\hline $\begin{array}{l}\text { Apatite } \\
\text { Number of analyses }\end{array}$ & $\begin{array}{c}\text { MB-10 } \\
45\end{array}$ & $\begin{array}{c}\text { Wilberforce } \\
11\end{array}$ & \multicolumn{1}{c}{$\begin{array}{c}\text { Durango } \\
5\end{array}$} \\
\hline $\mathrm{CaO}$ & $54.24(35)$ & $54.16(40)$ & $54.16(42)$ \\
$\mathrm{P}_{2} \mathrm{O}_{5}$ & $41.66(36)$ & $40.76(30)$ & $40.63(16)$ \\
$\mathrm{F}$ & $3.66(49)$ & $4.18(35)$ & $3.39(27)$ \\
$\mathrm{Cl}$ & $0.13(03)$ & $0.00(00)$ & $0.43(03)$ \\
$\mathrm{SrO}$ & $0.10(04)$ & $0.33(22)$ & $0.03(03)$ \\
$\mathrm{SO}_{3}$ & $0.01(01)$ & $0.54(06)$ & $0.36(05)$ \\
$\mathrm{Na}_{2} \mathrm{O}$ & $0.04(03)$ & $0.30(03)$ & $0.26(02)$ \\
$\mathrm{Total}$ & 99.83 & 100.27 & 99.25 \\
\hline
\end{tabular}

Note: Values in weight percent obtained during a single session by electron microprobe analysis for MB-10, Wilberforce, and Durango apatites. Numbers in parentheses are $1 \sigma$ errors.

can reconcile the observed track lengths with the predictions made by the Laslett et al. (1987) model.

Consideration of the temperature range of experiments on which annealing models are based yields insight into why some models offer predictions of track lengths that are closer to observed values than others (Table 6). Crowley et al. (1991) base their annealing model on more low temperature experiments than the others; the derived kinetic expression is weighted more heavily with low temperature results. Until annealing experiments evenly cover the entire spectrum of temperature and time, we suggest that a purely empirical approach to predicting the lengths of fission tracks in apatite suffers from the limitations of the experiments.

\section{CONCLUSIONS}

The combination of shallow sediment burial, near constant temperatures of deep ocean waters since the Cretaceous, and tectonic quiescence since the Cretaceous leads to the interpretation that sediments presently buried $270 \mathrm{mbsf}$ reached a peak temperature of $16^{\circ}-21^{\circ} \mathrm{C}$ at $96 \mathrm{Ma}$ and have since cooled. Apatites were recovered from volcaniclastic sandstones and contain natural fission tracks that are $14.6 \pm 0.1 \mu \mathrm{m}$ long, in contrast with mean fission track lengths of 14.8 to $15.9 \mu \mathrm{m}$ that are predicted by currently available models of fission track annealing. The results of this study reveal the possible pitfalls of extrapolating laboratory data on rates of processes to geological times.

\section{ACKNOWLEDGMENTS}

The authors wish to thank Exxon Production Research Company for permission to publish this paper; Rich Weiland, Rich Ketchum, Leslie White (all at University of Texas at Austin), and Jinny Sisson (Rice University) for sample preparation and analysis assistance; Sean Willet (Dalhousie University) for help with the Tioga calibration; Cathy Broxterman, James Talbot, and Steve Bergman (ARCO Oil and Gas Company) for the ${ }^{252} \mathrm{Cf}$ exposure procedure; and the Ocean Drilling Program for the core samples. Ralph Hockett made stable isotope measurements and David Webb performed the XRD analyses.

\section{REFERENCES}

Carlson, W. D., 1990. Mechanisms and kinetics of apatite fission-track annealing. Am. Mineral., 75:1120-1139.

Corrigan, J., 1991. Inversion of apatite fission-track data for thermal history information. J. Geophys. Res., 96:10347-10360.

Crowley, K. D., Cameron, M., and Schaefer, M. L., 1991. Experimental studies of annealing of etched fission tracks in fluorapatite. Geochim. Cosmochim. Acta, 55:1449-1465.

Donelick, R. A., 1991. Crystallographic orientation dependence of mean etchable fission track length in apatite: an empirical model and experimental observations. Am. Mineral., 76:83-91.
Donelick, R. A., and Miller, D. S., 1991. Enhanced TINT fission track densities in low spontaneous track density apatites using ${ }^{252} \mathrm{Cf}$-derived fission fragment tracks: a model and experimental observations. Nucl. Tracks Radiat. Meas., 18:310-307.

Donelick, R. A., Roden, M. K., Moores, J. D., Carpenter, B. S., and Miller, D. S., 1990. Etchable length reduction of induced fission tracks in apatite at room temperature $\left(\sim 23^{\circ} \mathrm{C}\right)$ : crystallographic orientation effects and "initial" mean lengths. Nucl. Tracks Radiat. Meas., 17:261-265.

Donelick, R. A., and Willett, S. D., 1989. Inverse modelling of apatite fission track length spectra and age to estimate temperature history. Eos, 43:1320.

Engebretson, D. C., Cox, A., and Gordon, R. G., 1985. Relative motions between oceanic and continental plates in the Pacific Basin. Spec. Pap.Geol. Soc. Am., 206.

Fleischer, R. L., Price, P. B., and Walker, R. M., 1965. Effects of temperature, pressure, and ionization of the formation and stability of fission tracks in minerals and glasses. J. Geophys. Res., 70:1497-1502.

Frakes, L. A., 1979. Climates Throughout Geologic Time: New York (Elsevier).

Gleadow, A.J.W., Duddy, L. R., Green, P. F., and Lovering, J. F., 1986. Confined track lengths in apatite-a diagnostic tool for thermal history analysis. Contrib. Mineral. Petrol., 94:405-415.

Green, P. F., 1980. On the cause of the shortening of spontaneous fission tracks in certain minerals. Nucl. Tracks, 4:91-100.

Green, P. F., Duddy, I. R., Gleadow, A.J.W., Tingate, P. R., and Laslett, G. M., 1986. Thermal annealing of fission tracks in apatite 1. A qualitative description. Chem. Geol. (Isot. Geosci. Sect.), 59:236-253.

Green, P. F., Duddy, I. R., Laslett, G. M., Hegarty, K. A., Gleadow, A.J.W., and Lovering, J. F., 1989. Thermal annealing of fission tracks in apatite: 4 . Quantitative modelling techniques and extension to geological time scales. Chem. Geol. (Isot. Geosci. Sect.), 79:155-182.

Green, P. F., and Durrani, S. A., 1977. Annealing studies of tracks in crystals. Nucl. Track Detect., 1:33-39.

Haq, B. U., and van Eysinga, F.W.B., 1987. Geological Time Scale: New York (Elsevier).

Harland, W. B., Armstrong, R. L., Cox, A. V., Craig, L. E., Smith, A. G., and Smith, D. G., 1989. A Geologic Time Scale: Cambridge (Cambridge Univ. Press).

Lancelot, Y., Larson, R. L., et al., 1990. Proc. ODP, Init. Repts., 129: College Station, TX (Ocean Drilling Program).

Laslett, G. M., Green, P. F., Duddy, I. R., and Gleadow, A.J.W., 1987. Thermal annealing of fission tracks in apatite. 2. A quantitative analysis. Chem. Geol. (Isot. Geosci. Sect.), 65:1-13.

McCrea, J. M., 1950. On the isotopic chemistry of carbonates and a paleotemperature scale. J. Chem. Phys., 18:849-857.

McKenzie, D., 1978. Some remarks on the development of sedimentary basins. Earth Planet. Sci. Lett., 40:25-32.

, 1981. The variation of temperature with time and hydrocarbon maturation in sedimentary basins formed by extension. Earth Planet. Sci. Lett., 55:87-98.

O'Neil, J. R., Clayton, R. N., and Mayeda, T. K., 1969. Oxygen isotope fractionation in divalent metal carbonates. J. Chem. Phys., 51:5547-5558.

Parsons, B., and Sclater, J. G., 1977. An analysis of the variation of ocean floor bathymetry and heat flow with age. J. Geophys. Res., 82:802-827.

Price, P. B., Lal, D., Tamhane, A. S., and Perelygin, V. P., 1973. Characteristics of tracks of ions of $14 \leq \mathrm{Z} \leq 36$ in common rock silicates. Earth Planet. Sci. Lett., 19:377-395.

Price, P. B., and Walker, R. M., 1962. Observation of charged particle tracks in solids. J. Appl. Phys., 33:3400.

Royden, L., and Keen, C. E., 1980. Rifting process and thermal evolution of the continental margin of Eastern Canada determined from subsidence curves. Earth Planet. Sci. Lett., 51:343-361.

Royden, L., Sclater, J. G., and von Herzen, R. P., 1980. Continental margin subsidence and heat flow: important parameters in formation of petroleum hydrocarbons. AAPG Bull., 64:173-187.

Silk, E.C.H., and Barnes, R. S., 1959. Examination of fission fragment tracks with an electron microscope. Philos. Mag., 4:970.

Smith, W.H.F., Staudigel, H., Watts, A. B., and Pringle, M. S., 1989. The Magellan Seamounts: Early Cretaceous record of the South Pacific isotopic and thermal anomaly. J. Geophys. Res., 94:10501-10523.

Date of initial receipt: 23 May 1991

Date of acceptance: 18 November 1991

Ms 129B-147 
A

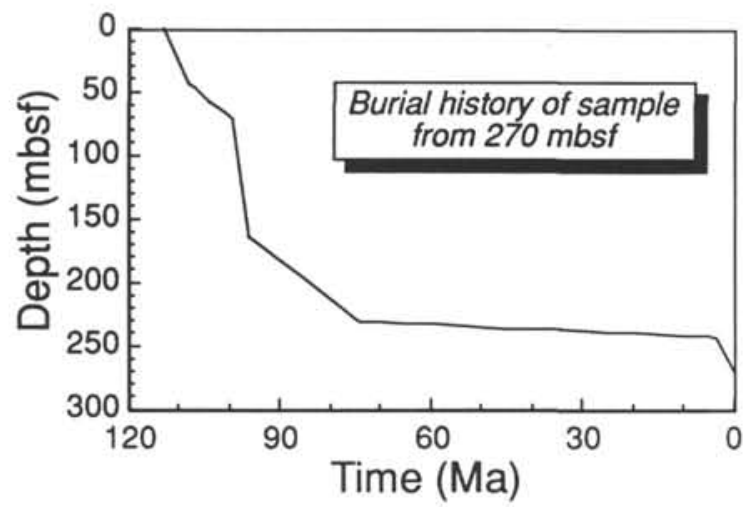

B

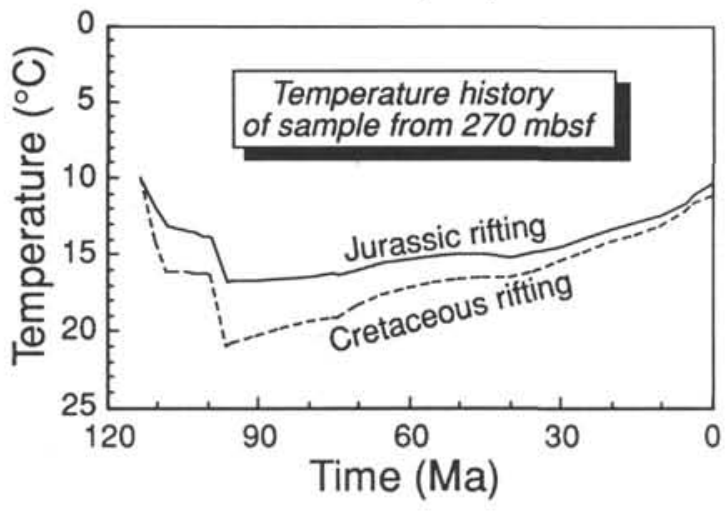

Figure 4 . Modeled history of bed currently at $270 \mathrm{mbsf}$. A. Burial history, accounting for 1-D compaction. B. Temperature history, assuming rifting occurred in the Jurassic (M33 $=163 \mathrm{Ma})$ and in the Cretaceous (126 Ma) and a temperature at the sediment-water interface as described in the text.

Table 5. Stable isotope data from calcite veins.

\begin{tabular}{lccc}
\hline Core, section, interval $(\mathrm{cm})$ & $\delta^{13} \mathrm{C}(\mathrm{PDB})$ & $\delta^{18} \mathrm{O}(\mathrm{SMOW})$ & Temperature $\left({ }^{\circ} \mathrm{C}\right)$ \\
\hline $129-800 \mathrm{~A}-$ & & & \\
$48 \mathrm{R}-2,15-16$ & 1.2 & 30.1 & 11 \\
$48 \mathrm{R}-2,58-61$ & 1.5 & 30.5 & 9 \\
$48 \mathrm{R}-3,12-15$ & 1.6 & 29.7 & 12 \\
50R-2, 139-142 & -0.6 & 27.2 & 23 \\
\hline
\end{tabular}

Note: Oxygen and carbon isotope ratios determined by standard $\mathrm{H}_{3} \mathrm{PO}_{4}$ technique of McCrea (1950). Results reported in standard $\delta$-notation (\%o) relative to PDB (carbon) and SMOW (oxygen) standards. Temperatures calculated using the calcite-water equilibration equation of O'Neil et al. (1969).

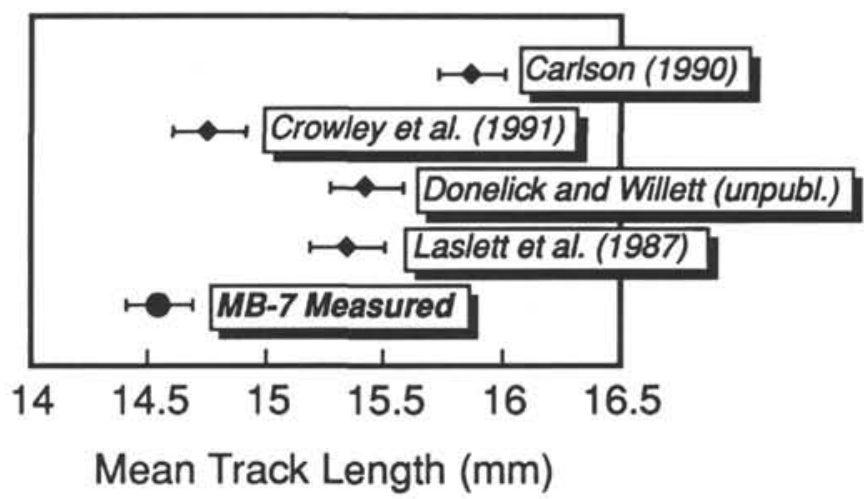

Figure 5. Comparison between the natural mean confined fission track length for sample MB-7 (solid circle) and the mean lengths predicted by the various apatite fission track annealing models (solid diamond). The temperature history used in the models is that for Site 800 at 270 mbsf (i.e., sample MB-7), assuming rifting occurred at $126 \mathrm{Ma}$ (see Fig. 3B). Except for the R. Donelick and S. Willett (unpubl. data, 1989) model calculation, an initial mean length (lo) of $16.15 \mu \mathrm{m}$ was used (Durango induced tracks in Table 2). The $\mathrm{R}$ Donelick and S. Willett (unpubl. data, 1989; after Crowley et al., 1991) model equation is $\left(\left[\left(1-\left(I / l_{o}\right)^{\beta}\right] / \beta\right)^{\alpha-} 1\right) / \alpha=c_{o}+c_{1}\left(\ln t-c_{2}\right) /\left[(1 / T)-c_{3}\right]$, where $\alpha=$ $0.87163, \beta=4.8503, c_{o}=-1.196, c_{1}=0.00001089, c_{2}=-11.070, c_{3}=$ 0.00089615 , and $l_{o}=17.30 \mu \mathrm{m}$ (these workers defined $l_{o}$ as the mean length to be expected at $\ln (t)=0$ at $23^{\circ} \mathrm{C}$ using the data of Donelick et al., 1990).

Table 6. Temperature distribution of laboratory-based annealing experiments.

Number of individual isothermal annealing experiments falling within these temperature ranges $\left({ }^{\circ} \mathrm{C}\right)$

\begin{tabular}{lccccc}
\multicolumn{1}{c}{ Apatite } & $<50$ & $50-99$ & $100-149$ & $150-199$ & $\geq 200$ \\
\hline a Durango & 0 & 3 & 4 & 4 & 66 \\
b Tioga & 9 & 0 & 2 & 8 & 64 \\
${ }^{\mathrm{c} B-5}$ & 1 & 5 & 11 & 8 & 27 \\
\hline
\end{tabular}

${ }^{2}$ Green et al. (1986).

'Donelick et al. (1990), Donelick (1991), and R. Donelick (unpubl. data, 1989).

${ }^{\circ}$ Crowley et al. (1991). 